\title{
Multiculturalist Aspect in Bharathi Mukherjee's Jasmine and Chitra Banerjee Divakaruni's arranged marriage
}

\author{
Akhila Raj
}

Faculty, Department of English, St. Dominic's College, Kanjirappally, Kerala, India

Received: 04 Apr 2021; Received in revised form: 07 May 2021; Accepted: 30 May 2021; Available online: 14 Jun 2021 (C2021 The Author(s). Published by Infogain Publication. This is an open access article under the CC BY license (https://creativecommons.org/licenses/by/4.0/).

\begin{abstract}
India is considered a heterogeneous society having multiple cultures. This philosophical system is represented by what is called 'unity in diversity'. In a multicultural society people of different cultures, races, ethnicities, nationalities live together. Several Indians migrated to totally different countries all over the world either as a part of colonization or for their work. Diasporic literature is the result of this migration. Cultural Pluralism, diversity or multiculturalism is apparent in diasporic literature especially in the works many Indian diasporic writers. Diasporic or migrant writers, particularly the Indian diaspora in the US and other parts of the world, have a noticeable impact on the contemporary literature. Some of the diasporic writers' works are largely set in India, America and parts of the world. Being immigrants, they are caught between various cultures. In their novels, we can trace the challenges of living in a multicultural world, and also the issues faced by the Indian communities there. There are some Diasporic writers who have established themselves in the literary world such as V S Naipaul, Chitra Banerjee Divakaruni, Bharathi Mukherjee, Anita Desai, Amitav Ghosh, Salman Rushdie, Jhumpa Lahiri, Shashi Tharoor, Meena Alexander, Kiran Desai etc. have attracted the readers through their uniqueness in themes, and the most important characteristics of these writers is the blending of various cultures. Whenever these writers accentuate the life of the characters in their novels, they use Indian culture or we can see the element of Indianness. This paper focuses on how multiculturalism influences the Diasporic writers like Bharathi Mukherjee and Chitra Banerjee Divakaruni.
\end{abstract}

Keywords-Cultural Pluralism, Diaspora, Diversity, Indianness, Multiculturalism.

\section{INTRODUCTION}

The word 'Culture' is used in our everyday life. It is the social environment in which we are living. 'Culture' is derived from the Latin word "Colere" which suggests 'to cultivate' or 'to civilize'. Culture is the cultivation of the human soul or mind. Human beings are a cultural package. There are many cultural differences among the people in their languages, beliefs, customs, traditions, arts and these are transmitted from generation to generation. Culture is an all-encompassing and integrated feature of these writers.

Multiculturalism or ethnic pluralism is a part of this globalized world. Multicultural society has been described as a "salad bowl model" because different cultures integrate and combine to form a single whole. For example, New York City can be considered as a 'salad bowl'. Multiculturalism forms without a dominant culture. India is a multicultural society because India's multiculturalism can be designated through multilingualism. Language has always played a great role in a state's political identity. Each state is allowed to use its language and customs in its states. Being a heterogeneous society there are multiple cultures in India, where religions and caste- systems are closely linked. India shows a positive idea towards ethnic pluralism because India allows all citizens to openly practice their cultures and put forward their definition of India and one dominant idea of India is not imposed upon the others. 


\section{DIASPORIC LITERATURE}

Colonialism was essentially an encounter between different cultures. 'Diaspora' is an important term in postcolonial discourse and it means 'scattering or dispersion'. The term diaspora refers to a group of people who were uprooted from their homeland to another cultural region for various reasons. They are caught physically between two cultures--- their own and the new one. During colonialism, many diasporic communities were formulated in our society. Some of the major diasporas of the past include the Aryan, African, Jewish, and Palestinian diaspora. In the present age of globalization, the terms like diaspora, expatriate, etc. have become very common phenomena. Migration or expatriation is a part of today's globalized world. According to a UN report published in 2020, India has the largest diasporic population in the world, distributed mainly in the USA, UAE, Saudi Arabia and other European countries.

The writings produced by authors living outside their homeland are called Diasporic or Expatriate literature. Meena Alexander defines it as, "writing in search of the homeland". Diasporic kinds of literatures mainly deal with 'home and foreign country' and between the 'familiar and strange'. Generally, the diasporic literature deals with themes of rootlessness, racial discrimination, identity crisis, dislocation, cross-cultural encounters, nostalgia and marginalization. India has produced many talented writers who had migrated to the US, Canada and other European Countries have to face various cultural conflicts. In their works, we can see the amalgamation of cultures and their yearnings for the homeland. While reading a diasporic writing, the readers trace multicultural aspects, and this uniqueness makes the literature of the diaspora to acclaim the status of great work. Indo-American diaspora is one among the important diasporas which has exerted a huge impact on the literary world and have fashioned literary geniuses of our time.

Bharathi Mukherjee, a versatile Indian- born Awardwinning American writer, is considered a writer of Immigrant life. Her oeuvres include the novels "The Tiger's Daughter", "Wife", "Jasmine", "The Holder of the World" and "Leave it to Me", her short stories include "Darkness" and "The Middleman and Other Stories". In her award-winning collection "The Middleman and Other Stories" and in the novels like "Jasmine", she explores the internal cultural clashes in her immigrant characters. Undoubtedly, we can consider her as the epitome of South Asian Immigrant writings. In her first novel "The Tiger's Daughter", Mukherjee deals with the issues related to the isolation of the Indian expatriate. Her life is one of the best examples of the mixing of two cultures, because she was born in India and then migrated to America. As an immigrant, she experiences cross-cultural issues and identity crises and, in her novels, we can see the mingling of two cultures. According to her, writing is always going against mainstream assumptions or complaisance. Mukherjee, in an interview, said that she saw herself as an American writer and not an Indian Diasporic one. She rejects hyphenation but never rejects her roots. Sometimes she wears a sari, the custom of Indians, and loves to go to the Durga Pooja celebration.

'Jasmine', one of the famous novels by Mukherjee, explores the cultural transformation that the protagonist undergoes. The protagonist Jasmine, a young Indian woman, tries to adapt to the American way of life to survive. She starts her life as Jyoti in India, where she stands against the role that was prepared for her by the patriarchal system of her homeland. Jyoti is very rebellious. After her marriage, she changes her name to Jasmine, her initial change to become a city girl. Jyoti seeks a contemporary and educated husband who keeps no faith in dowries and traditions, and thus finds a US based modern-thinking man, Prakash. Prakash encourages Jyoti to study English, and symbolically gives Jyoti a new name Jasmine, and a new life.

"He wanted to break down the Jyoti as I'd been in Hasnapur and make me a new kind of city woman. To break off the past, he gave me a new name: Jasmine. He said, "You are small and sweet and heady, my Jasmine. You'll quicken the whole world with your perfume". Jyoti, Jasmine: I shuttled between identities". (77)

The second part of the book deals with Jasmine's life in America and there she has to face more problems. After her husband's death, she migrated to America to fulfil her husband's mission. We can see Jasmine's constant shift from one identity to another. She reached America through illegal ways and doesn't know anything about the American way of life. Jasmine starts to feel loneliness and disillusionment, the problems faced by the expatriate community. She is not an expert in speaking English. She meets a kind-hearted white old lady who teaches her English and gives shelter for a few days. Then she decides to move to New York in order to pursue her goals. In the last part of the novel, Jasmine moves to Canada and where she married another man named Bud Ripple Meyer and settles in Iowa, and changes her name to Jane Ripple Meyer. The protagonist of the novel undergoes several transformations during her journey from New York city to Canada--- Jyoti to Jasmine to Jane.

Through this novel, Mukherjee portrays the multicultural crisis encountered by an Indian immigrant woman. In 
America, she tries to adopt the American way of life and leaves all her Indianness. There are some factors like language, dress and socio-cultural environment that deepen the problem of nation and identity after migration takes place. She faces the problem of acculturation.

"I could not admit that I had accustomed myself to American clothes. American clothes disguised my widowhood. In a T-shirt and cords, I was taken for a student. In this apartment of artificially maintained Indianness, I wanted to distance myself from everything Indian". (128)

Mukherjee through her character Jasmine shows the potential of a woman to remake herself in a New World. Uprooted from her native land India, Jasmine does her best to create a new world consisting of new ideas and values, and constantly unmasking her past to establish a new cultural identity into the new and alien society. This shows Mukherjee's own assimilation into the American way of life. Jasmine does not like to live a constant life; she adapts according to her situations. Through this novel, we can see her as a survivor, a fighter and an adapter. Jasmine's is the total transformation of an Indian body into an American soul. While defining this character, Bharati Mukherjee says, she considers Jasmine, and lot of her characters, as being people who are pulling themselves out of the very traditional world in which their fate is predetermined, their destiny resigned to the stars.

Chitra Banerjee Divakaruni is an award-winning IndianAmerican author and poet, who belongs to the category of expatriate literature. Her works are largely set in India and America and sometimes affect the experiences of the South-Asian immigrants particularly that of South Asian women. Chitra's first collection of short stories 'Arranged Marriage' (1994) won her an American Book Award, the Bay Area Book Reviewers Award, and the PEN Josephine Miles Award for fiction. Her other major works include 'The Mistress of Spices', 'Sister of my Heart', 'Queen of Dreams', 'Palace of Illusions', etc. Her works have been translated into 18 languages. Divakaruni was born in Kolkata, India. After completing her graduation, she moved to the USA to continue her higher studies. She earned a Ph.D. from the University of California. She moved to Texas after her marriage and now she is a professor of creative writing at the University of Houston.

For Divakaruni, her experience in a new land was very transformative and powerful because she came from a sheltered background. The experience of an expatriate was so different not only for her but for all others in her community. Divakaruni says that her writing starts through immigration experiences. In her novels she brings a contrast between Indian culture and American culture, mainly focuses on the lives of immigrant women battling cultural shackles. She also implements myth to present a vivid picture of Indian culture. She lived in India for 19 years before immigrating to the USA. Her works show the effect of globalization on the lives of individuals.

Chitra Banerjee Divakaruni' s story Arranged marriage is a collection of eleven short stories that specialize in Indian women whose lives are linked both to the Indian tradition of arranged marriage and the power changes by immigration to the USA. Through these stories, Divakaruni explores the immigrants' problems and discusses the contrasting cultural differences between the east and west. It shows how the Indian-born girls and women are being caught between the old and the new world values. These women struggle to carve out an identity of their own. The central theme of many of these stories is mother - daughter relationship and also focuses on the system of patriarchy. All the stories differ in the plot but revolve around the same theme. The stories of the collection address the issues such as identity-crisis, interracial relationships, emotional isolation, economic disparity, sexuality, abortion, and divorce. Divakaruni' s Arranged Marriage is about women who is in love, in relationships, and difficulties while trying to adapt to the new alien culture.

In one of the short stories 'Ultrasound', Divakaruni explores clashes between American and Indian values. The story deals with two--- friends-one in America and another in India - who are pregnant at the same time. The girl in America anticipates the birth of her child, while her friend in India faces the problem of deciding whether or not to abort her child because an ultrasound scanning indicates it is a female. Here we can see the American- Indian Cultural conflict.

'Arranged Marriage' is the problem of adjustment arising from cultural variation experienced by an Indian woman when she moves toward the west, which is an important theme in the mosaic of the American Indian culture. In the short story 'Clothes' Sumita, an Indian bride, living in America, has constantly been fed on traditional ideas that it is her moral duty to act as an honest Indian wife...serving tea to her in-laws' friends, covering her head with her sari, not addressing her husband by his name, etc. Sumita follows her Indian culture in her home in California and it reminds her of her homeland. After her husband's death, her in-laws want her to return to India, but she doesn't want to go back to India, her motherland. The conflict of consciousness and sense of assimilation is quite evident.

Similarly, in "Silver Pavements, Golden Roofs" the protagonist Jayanti being an immigrant faces many problems when she migrates from Calcutta to Chicago to 
live with her aunt Pratima and uncle Bikram. There she lives in between two worlds: the imaginary and the real, the past and the present, and the virtual and the material. In the story "Perfect life", Meera, an Indian girl, rejects the traditional roles of a wife and a mother in favour of her career and education in America. 'The Bats' is the story that presents the patriarchal system in India. In this story, Divakaruni doesn't provide any gender or name to the protagonist. The protagonist is married with a child but is a victim of the atrocities of the husband:

“.. . . . Not the dark circles under her eyes. Those were always there. It was high upon her cheek, a yellow blotch with its edges turning purple. It looked like my knee did after I beefed into the chipped mahogany dresser next to our bed last month" (P 2).

Unable to bear the ill-treatment, the protagonist leaves the house along with her child to her uncle's place. Divakaruni presents a typical Indian society that criticizes such women and so is forced to go back to her husband...

'The World Love' presents the mental trauma experienced by the Indian-born girls and women living in America and as immigrant, they balance between the old treasured beliefs and surprising new desires. In almost all the stories like The Bats, Clothes, Maid Servants Story, Meeting Mrinal, A Perfect Life, Doors, Affairs, Chitra Banerjee has painted the women in detail, pointing to the realities of life after marriage and the cultural disparity they face in an alien land. The women of these short stories experience a conflict of consciousness and struggle to define themselves like those of several South Asians and Americans. She says in an interview:

"Women, in particular, respond to my work because I'm writing about the women in love, in difficulties, women in relationships. I want people to relate to my characters, to feel their joy and pain, because it will be harder to be prejudiced when they meet them in real life."

\section{CONCLUSION}

There is no doubt the protagonists and their creators of the novels 'Jasmine' and 'Arranged Marriage', etc will remain forever in the minds of every reader. Through these works, we can trace the energetic and cheerful qualities of the first-generation Diasporic writers in the USA like Bharati Mukherjee and Chitra Banerjee Divakaruni. They are considered as the illustrious voices in the post-colonial era express fluently and coherently the dilemmas and problems of the expatriate community in the USA and the other world. These writers, through their simple narrative style, explores the identity crisis, loneliness and disillusionment faced by the immigrants mainly the Indian women. Mukherjee captures the impassioned and pivotal role of the immigrants in the world through her novels. In India marriage is considered as an institution. Divakaruni examines the traditional institution of the arranged marriage and its relevance across the time. As immigrant writers, both of them successfully and authentically has been able to express multicultural conflicts drawn from their alien life.

\section{REFERENCES}

[1] Banerjee Divakaruni Chitra, Arranged Marriage, A Black Swan Publications, London, 1997; p2

[2] Mukherjee, Bharati, Jasmine, Grove Press, New York, 1989; p1-150

[3] N. Kaushi Reddy. "Aspects of Enculturation and Acculturation in Bharathi Mukherjee's Jasmine: An Appraisal", IJRAR, Volume 5, Issue 3, July-September 2018; p520-524

[4] V.Poornima, C. Dhivya. "Diasporic Consciousness in Chitra Banerjee Divakaruni's Arranged Marriage", IJIRT, Volume 5, Issue 8, January 2019; p21-24.

[5] Nayar, K, Pramod, Postcolonial Literature an Introduction, Pearson India Education Services Pvt.Ltd, 2019; p186-208 